\title{
Implementation of Community Service in The Introduction of History in the Sembulungan Peninsula, Banyuwangi Regency, East Java Province Indonesia
}

\author{
Agus Mursidi1, Tofan Priananda Adinata², Abdul Shomad³, Dhalia Soetopo4, Miskawi ${ }^{5}$, Atim \\ Hariadi 6 \\ 1,2,3,4,5,6 History Education, Faculty of Teaching and Education, PGRI Banyuwangi University \\ Email: agusmursidi78@gmail.com \\ do \\ https://doi.org/10.36526/gandrung.v2i2.1354
}

\begin{abstract}
One of the relics whose existence must be preserved and preserved is in Banyuwangi Regency, precisely in Alas Purwo National Park (TN Alas Purwo), a national park located in Banyuwangi covering an area of 43,420 hectares. In addition to having a diversity of flora and fauna in the Alas Purwo National Park area, there are also many objects and buildings of the past, especially on the Sembulungan peninsula, which was formerly known as an entry and exit route for colonial trade commodities. However, let alone the student community who are academics who are not very familiar with the relics on the Sembulungan peninsula, the method used in this service is qualitative analysis by coming to the location directly and conducting observations and collecting data through structured interviews with a triangulation approach. The results show that students' insight has increased by looking at the relics of the Japanese military in maintaining power in the form of bunkers, cannons, and military strategies developed on the Sembulungan peninsula for maritime security.
\end{abstract}

Keyword: Implementation of Community Service, Historical Legacy, for Maritime Security

\section{Pendahuluan}

Peninggalan sejarah merupakan suatu warisan budaya yang menceritakan keluhuran dari suatu budaya masyarakat. Peninggalan sejarah yang tersebar di seluruh kepulauan Indonesia merupakan suatu kekayaan budaya yang harus dijaga dan dilestarikan keberadaannya. Dengan adanya berbagai peninggalan sejarah, bangsa Indonesia dapat belajar dari kekayaan budaya masa lalu yang berguna dalam kehidupan berbangsa dan bernegara.

Salah satu peninggalan yang keberadaannya harus dijaga dan dilestarikan berada di Kabuapeten Banyuwangi tepatnya di taman Nasional Alas Purwo (TN Alas Purwo), taman nasional yang terletak di Banyuwangi seluas 43.420 hektar. Selain memiliki keanekaragaman flora dan fauna di kawasan TN Alas Purwo juga banyak benda-benda dan bangunan peninggalan masa lalu khususnya di semenanjung sembulungan yang dahulu dikenal sebagai jalur keluar masuk komoditas dagang Kolonial (Mursidi \& Soetopo, 2019).

Peninggalan bersejarah yang terdapat di Semenanjung sembulungan antara lain Goa alami, 
GANDRUNG: Jurnal Pengabdian Kepada Masyarakat ISSN: 2721-6136 (Online)

Bunker Jepang dan Meriam. Akan tetapi banyak masyarakat yang tidak mengetahui akan keberadaan bangunan-bangunan tersebut dan masyarakat terlihat cenderung tidak peduli pada peninggalan sejarah tersebut bahkan. Kurangnya pengetahuan masyarakat akan sejarah membuat mereka cenderung menganggap bahwa peninggalan-peninggalan bersejarah tersebut bukanlah hal yang penting bahkan sebagian masyarakat menganggap peninggalan sejarah hanyalah bangunan tua yang tidak berarti apaapa (Hennida et al., 2017).

Padahal persepsi masyarakat terhadap benda-benda dan bangunan- bangunan peninggalan bersejarah merupakan hal penting dalam upaya menanamkan kesadaran untuk ikut berpartisipasi secara aktif dalam menjaga kelestarian peninggalan bersejarah (Uliontang et al., 2020). Begitu juga mahasiswa sebagai generasi muda harus lebih peka terhadap peninggalan masa lalu karena memiliki nilai edukasi.

\section{Sejarah}

Sejarah merupakan kesusasteraan lama, silsilah, asal-usul Sejarah juga merupakan kejadian yang terjadi pada masa lampau yang disusun berdasarkan peninggalan-peninggalan berbagai peristiwa. Dalam bahasa Yunani, kata sejarah disebut istoria, yang berarti belajar. Jadi, sejarah adalah ilmu pengetahuan yang mempelajari segala peristiwa, kejadian yang terjadi pada masa lampau dalam kehidupan umat manusia (Asvi Warman Adam, 2007).

Adapun menurut Sartono Kartodirdjo sejarah adalah rekonstruksi masa lampau atau kejadian yang terjadi pada masa lampau (Sudirman, 2014). Ada tiga aspek dalam sejarah, yaitu masa lampau, masa kini, dan masa yang akan datang. Masa lampau dijadikan titik tolak untuk masa yang akan datang sehingga sejarah mengandung pelajaran tentang nilai dan moral.

Pada masa kini, sejarah akan dapat dipahami oleh generasi penerus dari masyarakat yang terdahulu sebagai suatu cermin untuk menuju kemajuan dalam kehidupan bermasyarakat, berbangsa, dan bernegara. Peristiwa yang terjadi pada masa lampau akan memberi kita gambaran tentang kehidupan manusia dan kebudayaannya di masa lampau sehingga dapat merumuskan hubungan sebab akibat mengapa suatu peristiwa dapat terjadi dalam kehidupan tersebut, walaupun belum tentu setiap peristiwa atau kejadian akan tercatat dalam sejarah (M. Dien Madjid, 2014).

\section{Peninggalan Sejarah}

Peninggalan Sejarah Peninggalan sejarah merupakan benda-benda yang mempunyai nilai sejarah dan masih ada hingga kini. Berdasarkan pengertian tersebut peninggalan sejarah mempunyai ciri-ciri sebagai berikut (Khoirotun et al., 2014). 
a. Benda tersebut berasal dari masa lampau

b. Bernilai sejarah yang berarti bahwa benda tersebut terkait dengan peristiwa masa lalu

c. Benda tersebut masih ada hingga kini, baik dalam keadaan utuh maupun sudah rusak.

Peninggalan-peninggalan sejarah dapat diklasifikasikan berdasarkan bentuk atau jenisnya dan masanya (periode waktunya) (Salim Yulius, 2014)yaitu sebagai berikut:

1. Berdasarkan masanya

a. Peninggalan Masa Prasejarah.

Masa Prasejarah adalah masa dikenalnya tulisan. Pada masa ini manusia hidup dengan peralatan yang masih sederhana. Peralatan hidup yang mereka buat dari bahan yang mereka dapat dari alam seperti batu dan tulang. Perkembangan kehidupan manusia pada masa itu berkembang sangat lambat. Dari mulai masa berburu dan mengumpulkan makanan dengan kehidupan berpindah-pindah hingga masa bercocok tanam dan hidup menetap. Untuk mengungkap kehidupan prasejarah, para ahli menggunakan temuan-temuan fisik dari masa ini yang berupa fosil, alat perkakas dari batu dan alat perkakas dari tulang.

b. Peninggalan Masa Sejarah

Masa sejarah adalah masa telah dikenalnya tulisan oleh masyarakat. Dari peninggalan tertulis seperti prasasti dan kitab-kitab kuno, dapat diketahui lebih jauh kehidupan masyarakat masa lalu. Selain itu, bentuk-bentuk peninggalan lainnya berupa bangunan.

2. Berdasarkan Jenis Wujudnya Berdasarkan jenisnya, peninggalan sejarah dapat dikelompokkan ke dalam 4 macam yaitu:
a. Bangunan, seperti candi, masjid, gapura, istana, keraton, benteng
b. Patung arca
C. Prasasti
d. Karya sastra

\section{Kesejarahan}

Banyak faktor yang menyebabkan sehingga kesadaran sejarah siswa masih kurang, antara lain; 1) diakui kecenderungan kehidupan global yang cenderung mengabaikan nilai-nilai masa lalu; 2) muatan materi pelajaran yang tidak relevan dengan pembentukan kesadaran sejarah; 3) sistem yang kurang mendukung pengembangan kesadaran sejarah, misalnya mata pelajaran berbasis sosial (IPS dan sejarah) cenderung terabaikan karena tidak dijadikan mata pelajaran Ujian Nasional sehingga dipandang sebelah mata oleh siswa; 4) motivasi dan orientasi siswa yang terlalu pragmatis yakni mengganggap 
GANDRUNG: Jurnal Pengabdian Kepada Masyarakat ISSN: 2721-6136 (Online)

mata pelajaran eksak yang paling unggul karena dapat memberikan manfaat lebih besar dibandingkan pelajaran berbasis sosial; dan 5) faktor guru juga sangat berpengaruh terhadap rendahnya kesadaran sejarah siswa (Saripudin et al., 2021).

Kesadaran sejarah menurut (Kurniawan, 2020) merupakan "kegairahan untuk mengerti kembali akan situasi, arus waktu,mengapa sesuatu hal bisa terjadi dimasa lalu atau mengapa itu tidak terjadi. Kegairahan ini akan menjadikan tantangan untuk bisa dan mampu menghadapi masa depan dengan menjadi pelaku, menjadi penentu masa depannya sendiri. Kesadaran sejarah mempermatang manusia dalam hubungannya dengan kenyataan, menjadikannya tantangan untuk mampu menguasai nasib. Dengan kesadaran sejarah manusia menjadi merdeka, bebas dan mengerti persoalan yang dihadapi dalam kekinian sehingga bisa mengantisipasi masa yang akan datang dengan kreatif, yakni dengan menyadari porsi dan potensi kemanusiaan sebagai pembuat sejarah."

Menurut Moedjanto dalam (Aramdi, 2020) ada tiga Indikator kesadaran sejarah yaitu: "1). Keberanian berpijak pada fakta dan realitas. 2). Keinsyafan adanya continuity (kelangsungan atau kesinambungan dan change (perubahan). 3) Keinsyafan akan keharusan gerak maju yang terus menerus"Jika dianalisis lebih jauh indikator kesadaran sejarah sebagaimana dikutip di atas, sesungguhnya masih bersifat teoretis artinya masih abtsrak. Mencintai bangsa dan negara merupakan bentuk kesadaran sejarah.Indikator paling konkrit terkait dengan kesadaran sejarah adalah minat belajar sejarah. Selain itu, ditegaskan bahwa kesadaran sejarah secara konkrit berkaitan dengan beberapa unsur, yakni:semangat kebangsaan, nasionalisme, patriotisme atau cinta tanah air.

Indikator kesadaran sejarah dalam konteks cinta tanah air, nasionalisme, dan patriotisme, dapat dirinci dalam beberapa idikator sebagai berikut: Untuk indikator kesadaran sejarah di kelas, terdiri atas:Ruang kelas dipajang foto presiden dan wakil presiden, foto pahlawan, lambang negara, dan peta Indonesia (Amboro, 2020); Meletakkan bendera di depan kelas; disiplin masuk kelas; tepat waktu menyelesaikan tugas; Antusias dan tidak mudah menyerah dalam mengerjakan tugas; mau bekerjasamadan terbuka menerima perbedaan; menggunakan bahasa Indonesia yang baik dan benar ketika mengemukakan pendapat.Untuk indikator kesadaran sejarah di luar kelas (sekolah), terdiri atas:Disiplin mengikuti upacara bendera,menghormat bendera merah putih dengan benar; menyanyikan lagu Indonesia Raya dengan semangat; membuang sampah pada tempat yang telah disediakan; dan mau bergaul dan saling membantu antar umat beragama. Dalam membentuk karakter melalui peninggalan masa lalu terutama berhubungan dengan kesadaran kebangsaan, cinta tanah air dan nasionalisme.

Pentingnya nilai dari peninggalan bersejarah tersebut dapat menjadi sesuatu yang bernilai tinggi 
GANDRUNG: Jurnal Pengabdian Kepada Masyarakat ISSN: 2721-6136 (Online)

serta dapatmenjadi sebuah ikon budaya bagi daerah mereka disamping warisan budaya tersebut sangat penting sebagai sumber pengetahuan dan pembelajaran sejarah lokal guna membangun karakter bangsa (Saripudin et al., 2021). Karenanya suatu perancangan mediagrafis yang dapat menumbuhkan rasa ingin tahu tanpa menggurui dan juga menumbuhkan rasa cinta terhadap bangunan- bangunan bersejarah terutama untuk generasi muda sangat dibutuhkan.

Maka dari itu, penelitian di Semenanjung sembulungan menjadi penting dilakukan guna membentuk kesadaran mahasiswa melalui peninggalan- peninggalan sejarah yang berada di semenanjung sembulungan. Upaya ini dilakukan dengan menginventarisasi, mencari serta mengidentifikasi bangunan- bangunan bersejarah yang ada di Semenanjung sembulungan, agar dapat dilestarikan dan dimanfaatkan tanpa menghilangkan nilai sejarahnya (Saripudin et al., 2021). Dan menjadi sesuatu yang sangat berguna dan berharga bagi masyarakat yang terdapat di wilayah ini, melalui upaya pelestarian terhadap bangunan-bangunan tua yang bersejarah.Mengingat begitu pentingnya akan peninggalan bangunan-bangunan bersejarah itu serta untuk memperkenalkan dan menyelamatkan bangunan bersejarah tersebut kepada pemerintah dan masyarakat sekitar, maka sangat tertarik untuk melakukan penelitian mengenai "benda dan bangunan-bangunan bersejarah di semenanjung sembulungan sebagai pembentukan kesadaran ".

\section{Metode}

Strategi pengabdian ini adalah observasi lapangan melalui studi peninggalan sejarah masa pendudukan jepang dengan melibatkan 35 mahasiswa pendidikan dejarah dengan di damping 6 dosen pendidikan sejarah dari Universitas PGRI Banyuwangi dengan melibatkan tenaga dari dinas perhutani taman nasional Alas Purwo. Pengabdian ini dilaksanakan di semenanjung sembulungan yang merupakan tempat peninggalan militer jepang dalam mempertahankan daerah jajahanya. Kegiatan ini dilaksanakan selam tiga bulan mulai dari perencanaan dan pelaksanaan dan laporan kegitan. Melalui teknik kualitatif triangulasi (Noviandari, 2019).

\section{Hasil dan Diskusi}

Semenanjung Sembulungan yang merupakan merupakan salah satu wilayah di kawasan TN Alas Purwo atau lebih tepatnya berada di wilayah Resort Sembulungan, SPTN Wilayah II Muncar. Sembulungan banyak menyimpan potensi sejarah dan budaya mulai zaman Prasejarah, Kerajaan Majapahit- Blambangan, Penjajahan Kolonial Belanda-Jepang. Berikut hasil inventarisasi dan deskripsi potensi yang ada di Semenanjung Sembulungan mulai dari keberadaan makam, Goa, Bunker dan 
GANDRUNG: Jurnal Pengabdian Kepada Masyarakat ISSN: 2721-6136 (Online)

meriam.

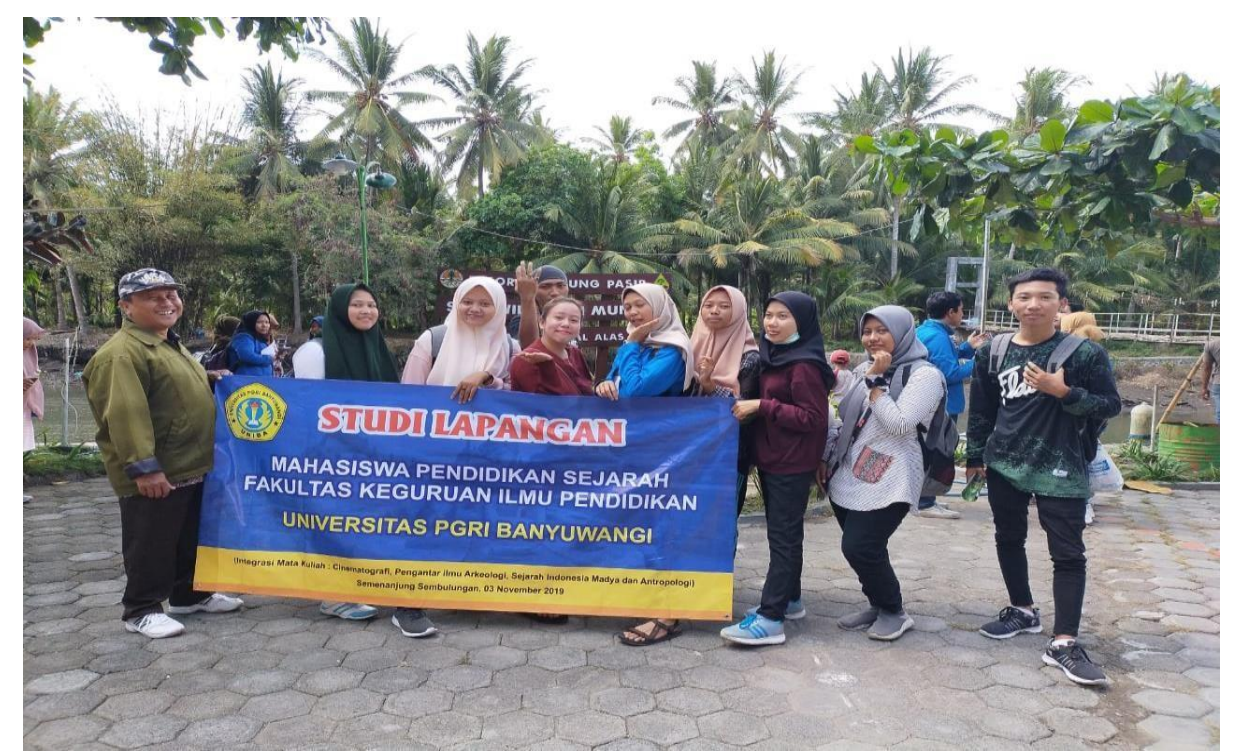

Gambar 1. Mahasiswa Pendidikan Sejarah Melaksanakan Studi Lapang Di Semenanjung Sembulungan (Sumber: Dokumentasi Pribadi 2020)

\section{Makam}

a. Deskripsi Makam

Keberadaan makam oleh masyarakat dihubungkan dengan petik laut. Berdasarkan hasil deskripsi keberadaan makam, bangunan tersebut terlihat cukup menonjol di antara gubukgubuk lain di pantai berpasir putih. Kompleks makam juga dikelilingi pagar tembok. Bangunan inti makam itu dikelilingi tembok dan ditutup atap genting. Lantai bangunan dilapisi keramikwarna putih dan tidak ada juru kunci dan bahkan tidak ada yang merawat makam.

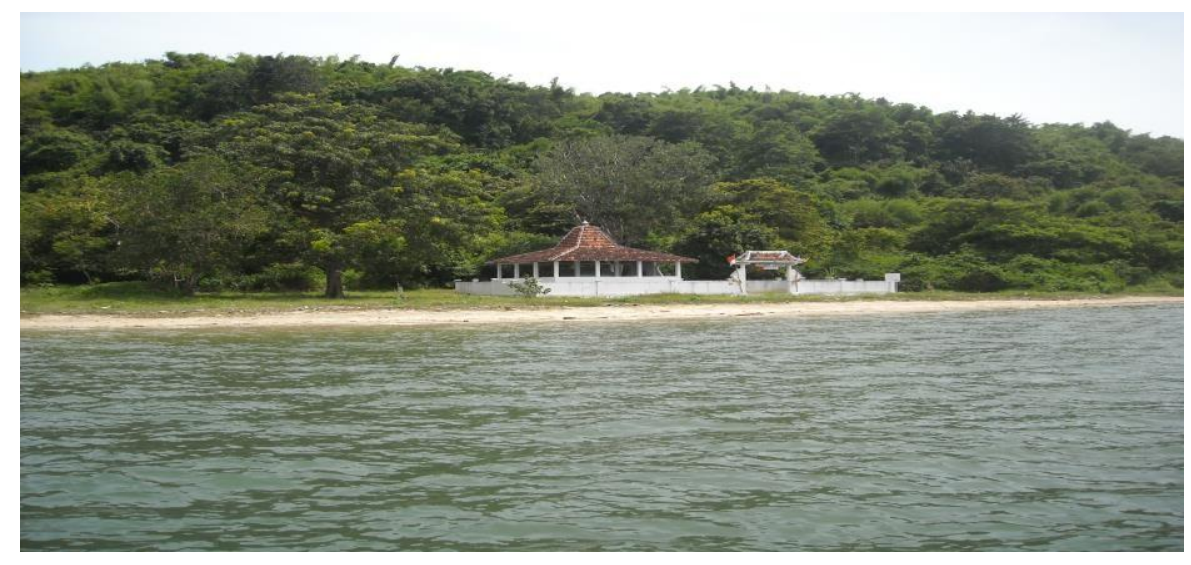

Gambar 2. Makam Terlihat Dari Jauh Yang Diyakini Oleh Masyarakat Sebagai Makam Yang Dikeramatkan Hingga Saat Ini (Sumber: dokumentasi pribadi 2020) 
Tepat di tengah bangunan itu terdapat tirai putih, semacam kain kafan, yang mengelilingi se kaligus menutup makam. Jarak kain pembatas dengan makam sekitar 1,5 meter. Kain itu dipasang mirip seperti penutup dipan (tempat tidur) kuno yang berfungsi sebagai pelindung nyamuk. Ketika tirai tersebut dibuka, ter lihat dua makam yang posisinya berdampingan. Dilihat dari bentuk dan jenis nisannya, makam tersebut diperkirakan su dah berumur puluhan hingga ratusan tahun.

Namun, sejarah asal-muasal makam tersebut masih belum begitu jelas banyak versi yang berkembang di masyarakat terkait sosok tokoh yang dimakamkan di lokasi tersebut. Salah satu versi yang beredar di masyarakat Muncar, makam tersebut merupakan makam sepasang penari gandrung di masa lalu. Konon, saat itu tengah digelar upacara tradisi petik laut di Perairan Muncar.

Berdasarkan hasil penelitian (Azizah \& Turyati, 2011) bahwa Orang yang pertama kali membuka daerah Muncar tersebut sangat menyukai kesenian Gandrung. Saat itu, diajatuh cinta kepada salah seorang penari Gandrung,dan setiap malam bulan purnama dia selalu nanggap gandrung. Setelah dia meninggal dan dimakamkan diTanjung Sembulungan, penari Gandrung yang dicintainya selalu berkunjung ke makamnya, hingga suatu ketika penari Gandrung tersebut meninggal dan dimakamkan di dekat pantai Tanjung Sembulungan. Berdasarkan mitos tersebut, setiap Petik Laut di Pantai Muncar wajib menghadirkan penari Gandrung. Ada warga yang menyebut makam tersebut merupakan makam Mbah Gandrung.

Sementara itu, versi lain menyebutkan, makam tersebut merupakan makam Sayid Yusuf. Sayid Yusuf dikenal sebagai tetua nelayan Muncar. Pada se tiap kegiatan petik laut Muncar selalu diadakan ziarah ke ma kam tersebut. Pada masa hidupnya, Sayid Yusuf sangat menyukai Gandrung, sehingga ku burannya disebut dengan makam gandrung. Bahkan, setiap petik laut, kesenian Gandrung dipentaskan di sekitar makam. Itu untuk menghormati sang tetua.

Versi lain menyebutkan, kompleks tersebut adalah makam Mbah Kalong. Namun, referensi yang menyebutkan tentang figur Mbah Kalong itu sangat minim. Biasanya, warga Banyuwangi, Situbondo, dan sekitarnya, yang berziarah kelokasi itu menyebut makam itu se bagai tempat peristirahatan yang terakhir Mbah Kalong. Ada pula yang menyebut makam ini sebagai makam keramat Mbah Agung Kalong.

Acara petik laut dilaksanakan setiap bulan muharram atau dalam Jawa disebut dengan bulan suro tampaknya bukan hanya kaum petani,masyarakat nelayan pun ikut menggelar ritual 
dalam bulan suro tersebut. Waktu pelaksanaan petik laut tiap tahun bisa berubah karena berdasarkan kesepakatan pihak nelayan. Biasanya digelar saat bulan purnama, tepat pada penanggalan Jawa, yaitu pada tanggal 15, karena pada waktu itu nelayan tidak melaut, mengingat pada saat itu terjadi air laut pasang.

Penyelenggaraan ritual petik laut dipadati dengan serangkaian acara yang biasa berlangsung selama tiga hari. Hari pertama, sebelum melepas semua sesaji ke laut, masyarakat nelayan mengadakan pengajian di masjid dengan membaca surat yāsin dan membaca tahlil. Hari berikutnya, acara pengajian dilanjutkan dengan membaca keseluruhan isi Al-Qur'an (khataman). Di hari terakhir, yang merupakan acara puncak, masyarakat nelayan mengadakan acara pemberian sesaji ke laut. Sebelum sesaji dilarung ke laut, ditampilkan terlebih dahulu tari-tarian tradisional masyarakat using, yaitu tarian gandrung. Tari Gandrung sendiri, dalam tradisi using, memiliki makna semangat perjuangan dan kebersamaan.

b. Nilai-nilai dalam petik laut sebagai pembentukan kesadaran sejarah.

Nilai religi yang terkandung dalam upacara Petik Laut ini di antaranya ialah pertama, permohonan pada Tuhan agar para nelayan dianugerahi hasil laut yang melimpah pada tahun yang akan datang. Kedua, sebagai salah satu media permohonan kepada Tuhan yang Maha Esa, agar selalu diberikan perlindungan, dijauhkan dari marabahaya dan dianugerahi keselamatan. Ketiga, wujud mensyukuri rahmat Tuhan Yang Maha Esa yang telah dilimpahkan berupa hasil penangkapan ikan yang tidak kunjung henti sepanjang musim. Keempat, sebagai salah satu upaya menanamkan perasaan cinta bahari bagi masyarakat nelayan Muncar, sehingga kehidupan laut yang telah mendatangkan manfaat dapat terpelihara secara lestari. Disisi lain juga terdapat nilai sosial yang dapat dirasakan dalam pelaksanaan Tradisi Petik Laut dikatakan dapat meningkatkan solidaritas sosial, hal ini dikarenakan dari pelaksanaan upacara keagamaan dapat tercapai keharmonisan antara manusia dengan sesamanya dan sebagai sarana interaksi sosial secara terus menerus hingga menumbuhkan integrasi sosial atau solidaritas sosial, sebab setiap ritual keagamaan akan melekat pada seluruh atau bagian dari anggota masyarakat yang dapat bekerja sama dengan baik.

Dengan menanamkan arti penting dari pelaksanaan tradisi petik laut, diharapkan generasi muda akan memiliki kesadaran serta semangat dalam mempertahankan tradisi petik laut tersebut. Selain itu masyarakat pesisir serta nelayan memiliki kepercayaan apabila tradisi petik laut ini tidak dilaksanakan maka masyarakat pesisir akan terserang wabah penyakit, akan terjadi kecelakaan laut bagi nelayan dan hasil tangkapan ikan nelayan akan sedikit. Hal ini 
GANDRUNG: Jurnal Pengabdian Kepada Masyarakat ISSN: 2721-6136 (Online)

terbukti setelah diadakannya tradisi petik laut ini hasil tangkapan ikan nelayan akan bertambah serta kehidupan masyarakat menjadi tentram dan damai.

\section{Bungker dan Goa Jepang}

Keberadaan bungker tidak dapat dilepaskan dari sejarah jepang terutama meletuskan perang pasifik, yang mana perang ini adalah ambisi dari Jepang bertujuan untuk membangun suatu imperium di Asia, serta dapat menguasai dan memiliki bahan-bahan industri diperoleh dari setiap negara-negara yang terletak di bagian selatan Jepang, termasuk Indonesia.

Pada tanggal 8 Maret 1942 Jepangtelah berhasil menduduki Indonesiaberkat serangan yang mereka lakukan terhadap Belanda, sehingga Belandaharus pergi dan melepaskan Indonesiasebagai Negara jajahannya kepada Jepang Sepenuhnya. Maka, Indonesia saat itu sah menjadi daerah jajahan Jepangdan semua aspek yang ada di Indonesiaharus tunduk dan patuh terhadap kebijakan yang Jepanglakukan.

Pada saat pendudukan Jepang di Indonesia,mereka mulai waspada dan berjaga-jaga atas setiap serangan yang bisa terjadi kapan saja oleh pihak lawan untuk merebut Indonesiakembali menjadi daerah jajahan mereka. Maka dari itu kekuatan militer Jepangmulai diperkuat dari segi apapun, salah satunya yaitu dengan membangun bangunan benteng, goa-goa, dan bunkerbunkeryang mana bertujuan utnuk memantau pergerakan dan serangan yang tiba-tiba bisa terjadi kapanpun. Jepangmembuat bangunan benteng, goa-goa, serta bunker-bunkeritu dengan gaya arsitekturyang unik dan dianggap kokoh bagi militer Jepang pada saat itu, banyaknya bunkeryang dibuat oleh Jepangdi setiap bantaran pantai, menunjukkan bahwa kewaspadaan serta pertahanan Jepang dalam melindungi wilayah kekuasaannya sangat penuh perhitungan.

Pembuatan bunker ini bertujuan untuk dapat memantau dan mempertahankan setiap daerah yang telah dikuasai Jepangpada masa penjajahannya di Indonesiadari serangan-serangan musuh yang ingin masuk, mendarat disaat terjadinya perang. Banyaknya bunker-bunker yang dibuat oleh Jepang di setiap pinggiran pantai, menunjukkan bahwa kewaspadaan serta pertahanan Jepang dalam melindungi wilayah kekuasaannya sangat diwaspadai. Dalam proses pembuatanbunker,pemerintahan Jepangbanyak melibatkan dari penduduk Indonesia (Pribumi) dengan sistem kerja paksa dan kasar (Romusa).

Bunker-bunker Jepang yang sengaja dibuat oleh para tentara Jepang ini masih bisa kita lihat dengan jelas di Sembulungan. Awalnya bunker-bunker ini sengaja dibuat dan difungsikan sebagai pos-pos pengintaian yang berguna untuk antisipasi serangan dari musuh. Keberadaan Bungker berada dipinggir pantai. berdasarkan informasi yang berkembang bahwa bungker terkenal angker. 
GANDRUNG: Jurnal Pengabdian Kepada Masyarakat ISSN: 2721-6136 (Online)

terlepas dari hal itu, bahwa kenyataannya bunker-bunker ini merupakan salah satu peninggalan bersejarah yang patut untuk tetap dirawat dan dijaga agar tidak lenyap dan hilang.

Berdasarkan hasil penelitian Achmad Maulana (Pengendali Ekosistem Hutan, BTN Alas Purwo) terdapat 24 Bungker Jepang dengan 3 jenis bentuk Bungker yaitu Bungker dengan 1 ruangan, Bungker dengan 2 Ruangan dan Bungker dengan Multiruang Namun karena kunjungan mahasiswa terbatas hanya 1 hari maka yang dilakukan adalah melakukan inventarisasi dan pendeskripsian yang dapat dijangkau termasuk goa karst alami yang menjadi habitat dari ribuan kelelawar.Gua Jepang yang berada di kawasan Taman Nasional Alas Purwo ini tepatnya berada di tengah-tengah hutan bambu di wilayah II Muncar Resort Sembulungan. Perjalanan dari Bibir pantai kelokasi Goa Jepang sekitar 1,5 kilometer. Perjalanan itu melewati tebing yang menanjak dan hutan bambu. Gua Jepang ini merupakan lubang alami di bawah tanah yang memiliki ukuran cukup besar dan dalam. Keberadaan gua dan bunker-bunker yang ditemukan di Taman Nasional Alas Purwo ini menunjukkan ciri khas sarana militer Jepang, yakni dibangun dengan memanfaatkan kondisi lingkungan.

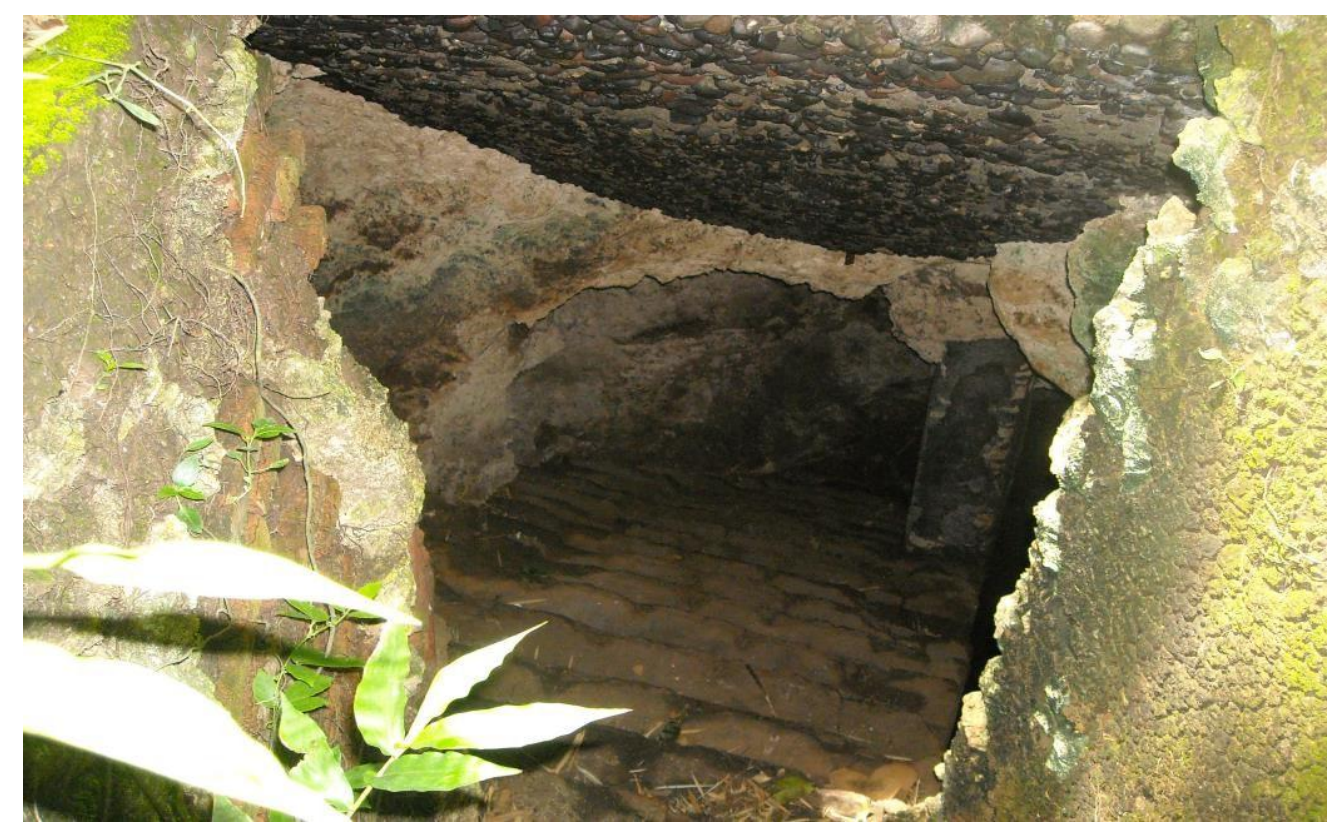

Gambar 3. Goa Karst Alami Yang Menjadi Habitat Dari Ribuan Kelelawar (Sumber: dokumentasi pribadi 2020) 
GANDRUNG: Jurnal Pengabdian Kepada Masyarakat ISSN: 2721-6136 (Online)

Pintu masuk ke gua berbentuk segi empat dengan lebarnya $50 \mathrm{~cm}$. Kedalaman gua sendiri mencapai 20 meter. akses masuk gua di sebelah timur laut berupa 22 anak tangga. Anak tangga kedua berbelok ke kanan yang terdiri dari 19 buah. Terdapat 3 kamar, 1 halaman, dan 1 pintu menuju lautan. Pintu menuju lautan inilah dihuni banyak ular berbisa dan ular jenis piton, anak tangga kedua ini menuju ke lantai dasar gua. Di samping tangga, terdapat lorong yang diperkirakan menuju arah pantai. Didalam goa terdapat banyak kelelawar dan kotoran.

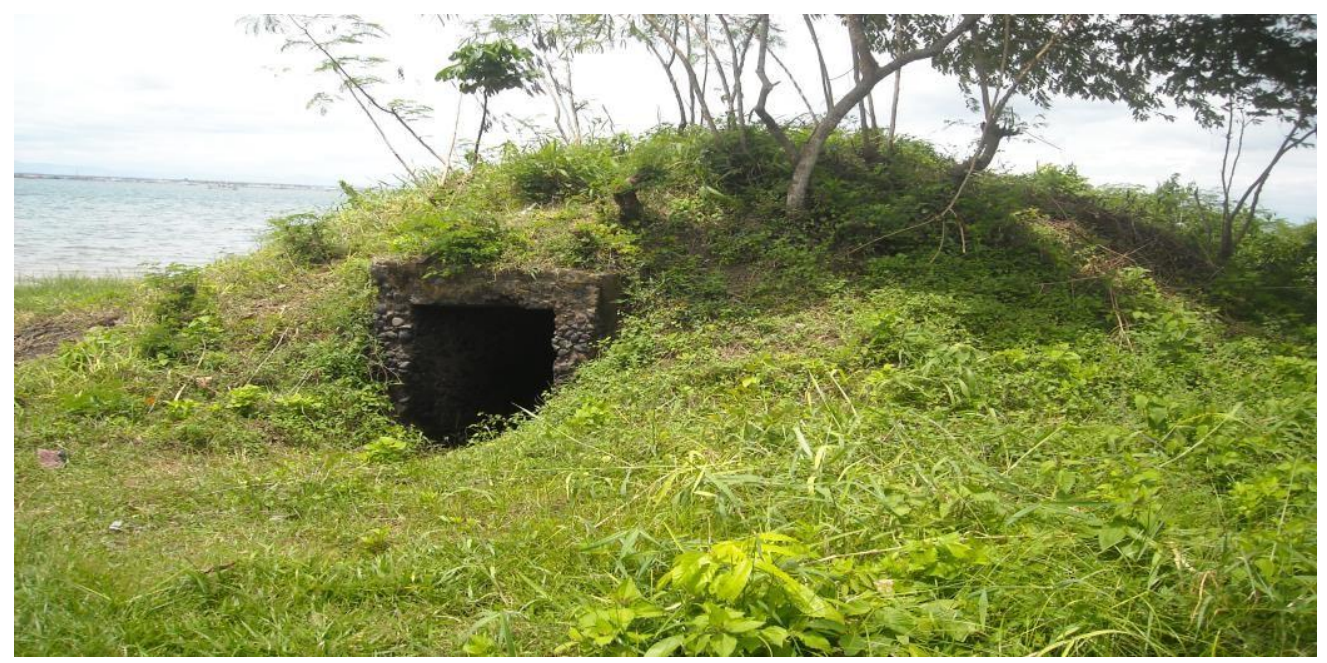

Gambar 4. Salah Satu Bungker Yang Terdapat Disemenanjung Sembulungan Yang Berada Tepat Dipinggir Pantai (Sumber: Miskawi, 2016)

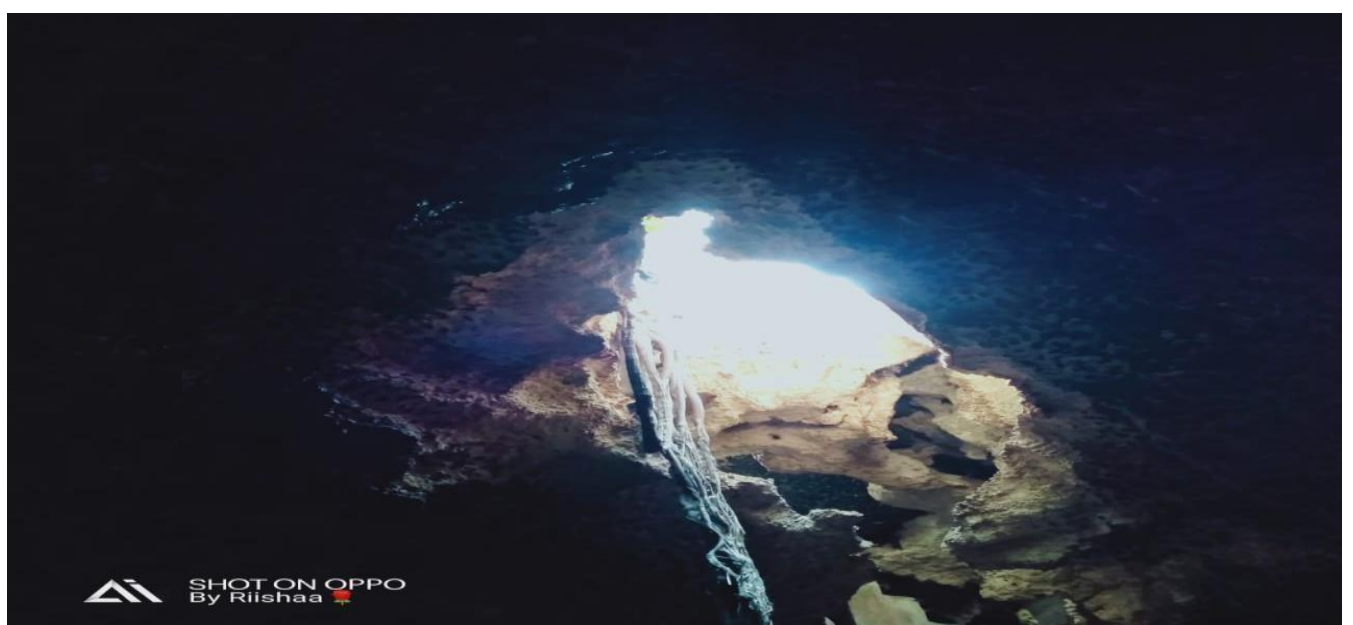

Gambar 5. Pintu Goa Tampak dari Bawah keatas (dokumentasi pribadi 2020)

3. Meriam

Terdapat 2 (dua) Meriam Jepang 1 berukuran kecil dan 1 meriam besar berukuran panjang 5 meter dan berat sekitar 4-5 Ton, pada bibir meriamnya tertulis Germany Esen Tahun 1900 yang diduga adalah tempat dan tahun pembuatannya. Besarnya meriam tersebut, sehingga hasil penelitian dapat menyimpulkan sebagai meriam terbesar yang ada di Indonesia. 
GANDRUNG: Jurnal Pengabdian Kepada Masyarakat ISSN: 2721-6136 (Online)

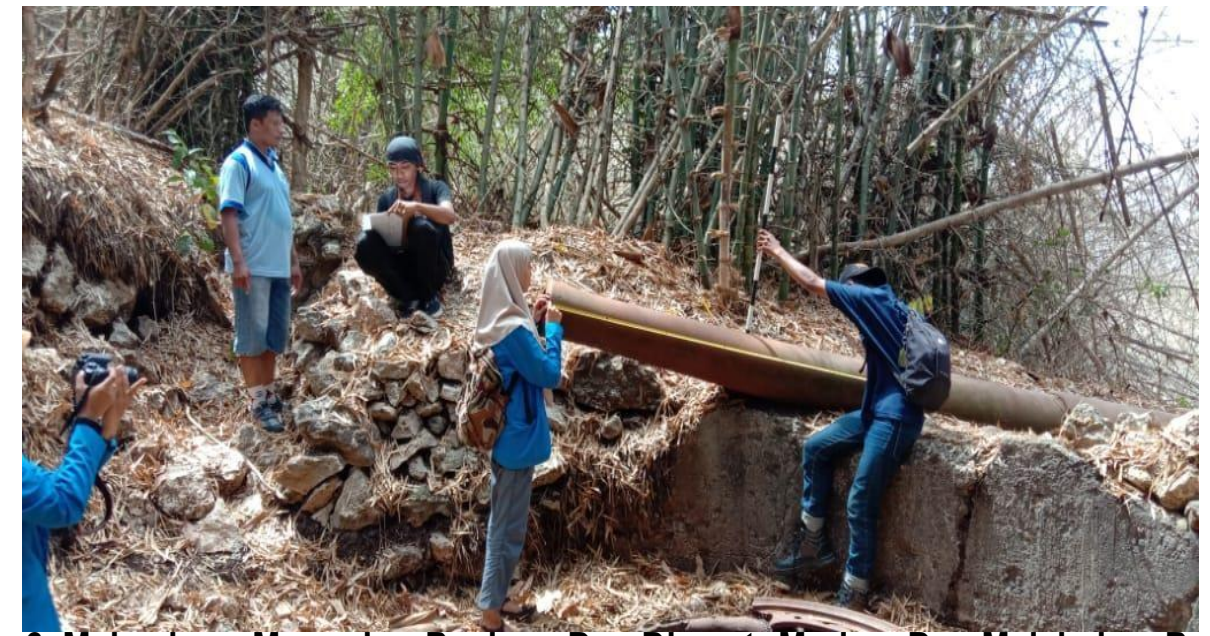

Gambar 6. Mahasiswa Mengukur Panjang Dan Diametr Meriam Dan Melakukan Pencatatan.

(Sumber: dokumentasi pribadi 2020)

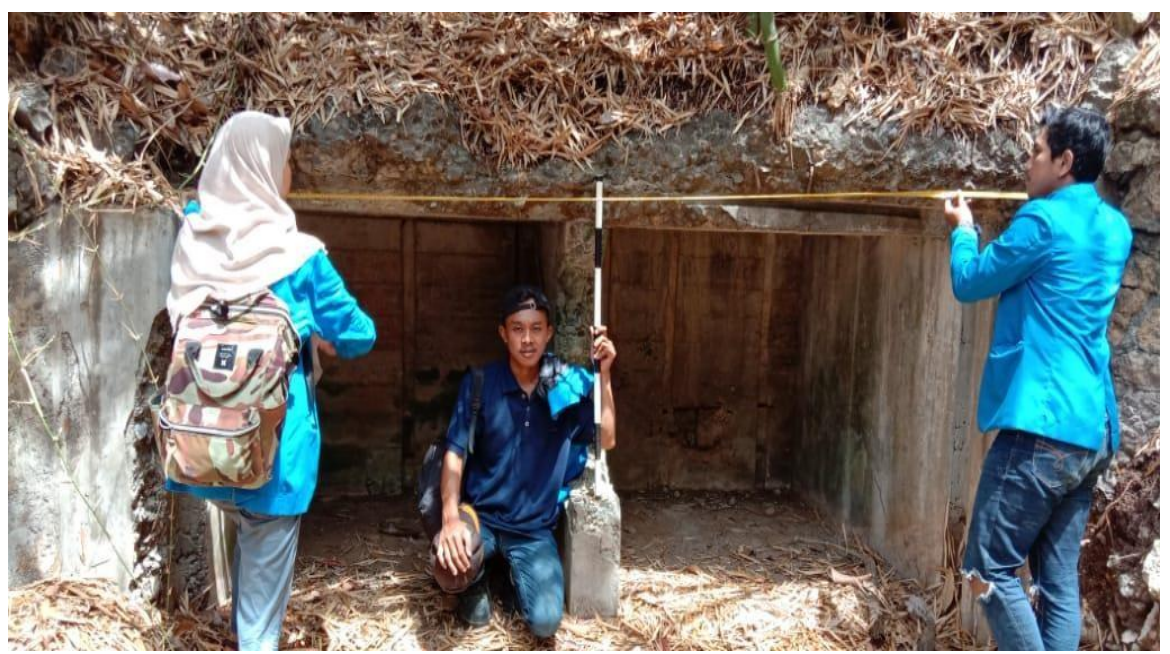

Gambar 7. Mahasiswa Mengukur Panjang Dan Diametr Meriam Dan Melakukan Pencatatan.

(Sumber: dokumentasi pribadi 2020)

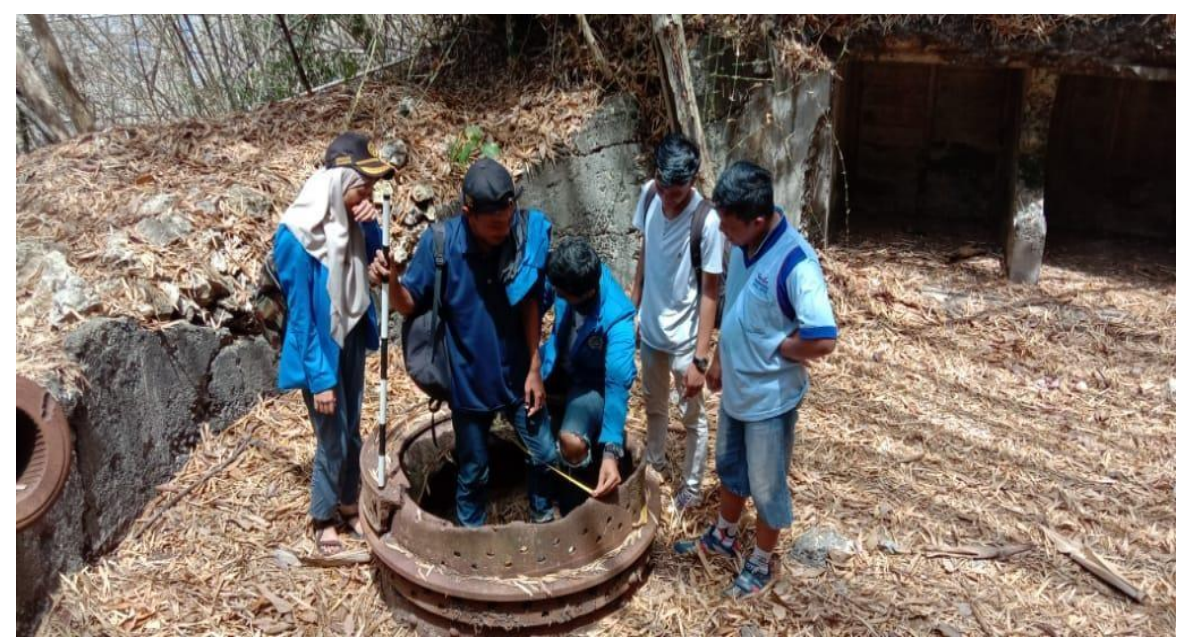

Gambar 7. Mahasiswa melakukan pengukuran disekitar Meriam. Tempat ini diperkirakan tempat logistik seperti bom (Sumber: dokumentasi pribadi 2020). 
GANDRUNG: Jurnal Pengabdian Kepada Masyarakat ISSN: 2721-6136 (Online)

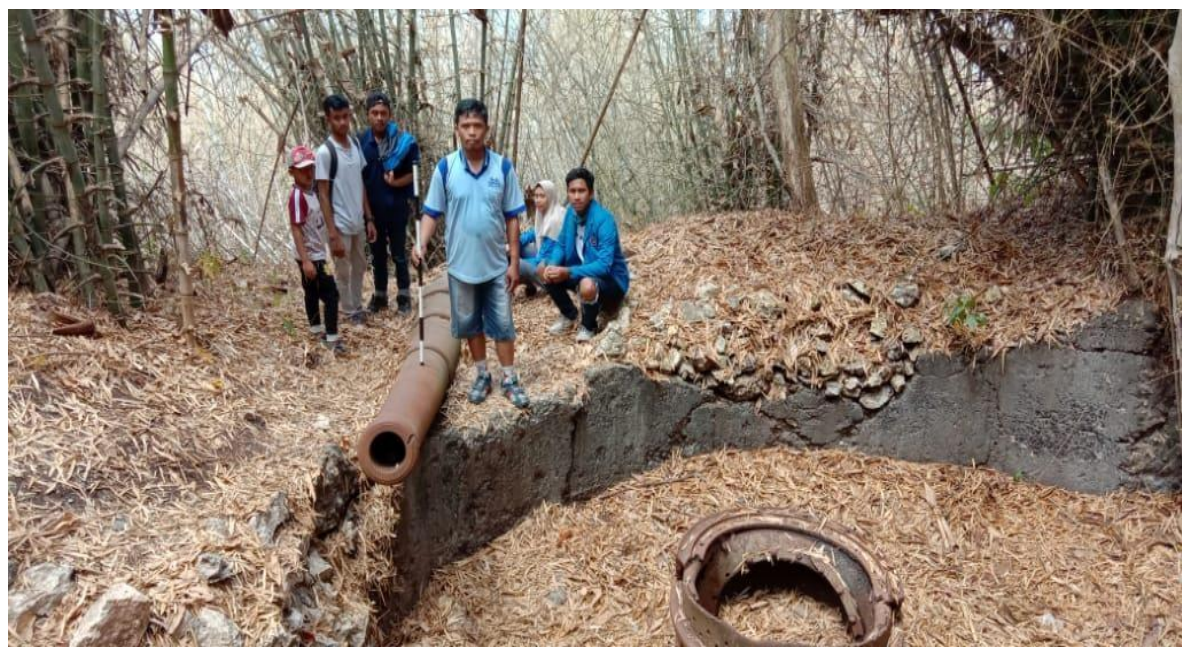

Gambar 8. Mahasiswa melakukan pengukuran disekitar Meriam. Tempat ini diperkirakan tempat logistik seperti bom (Sumber: dokumentasi pribadi 2020).

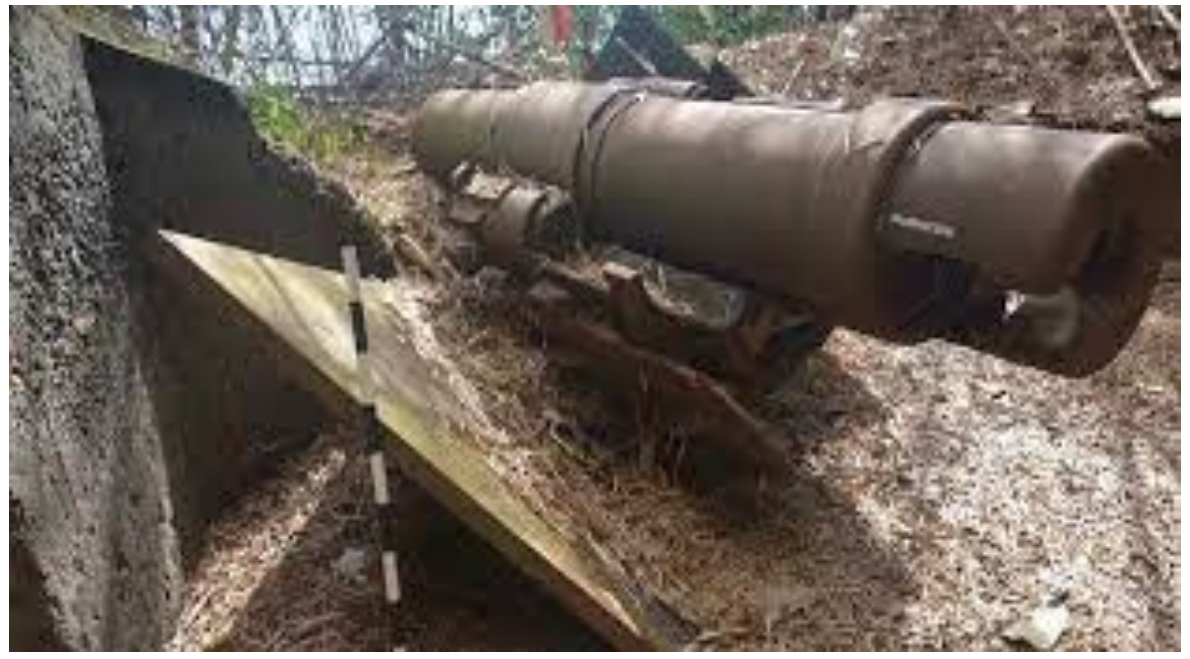

Gambar 9. Mahasiswa melakukan pengukuran disekitar Meriam. Tempat ini diperkirakan tempat logistik seperti bom (Sumber: dokumentasi pribadi 2020). 
GANDRUNG: Jurnal Pengabdian Kepada Masyarakat ISSN: 2721-6136 (Online)

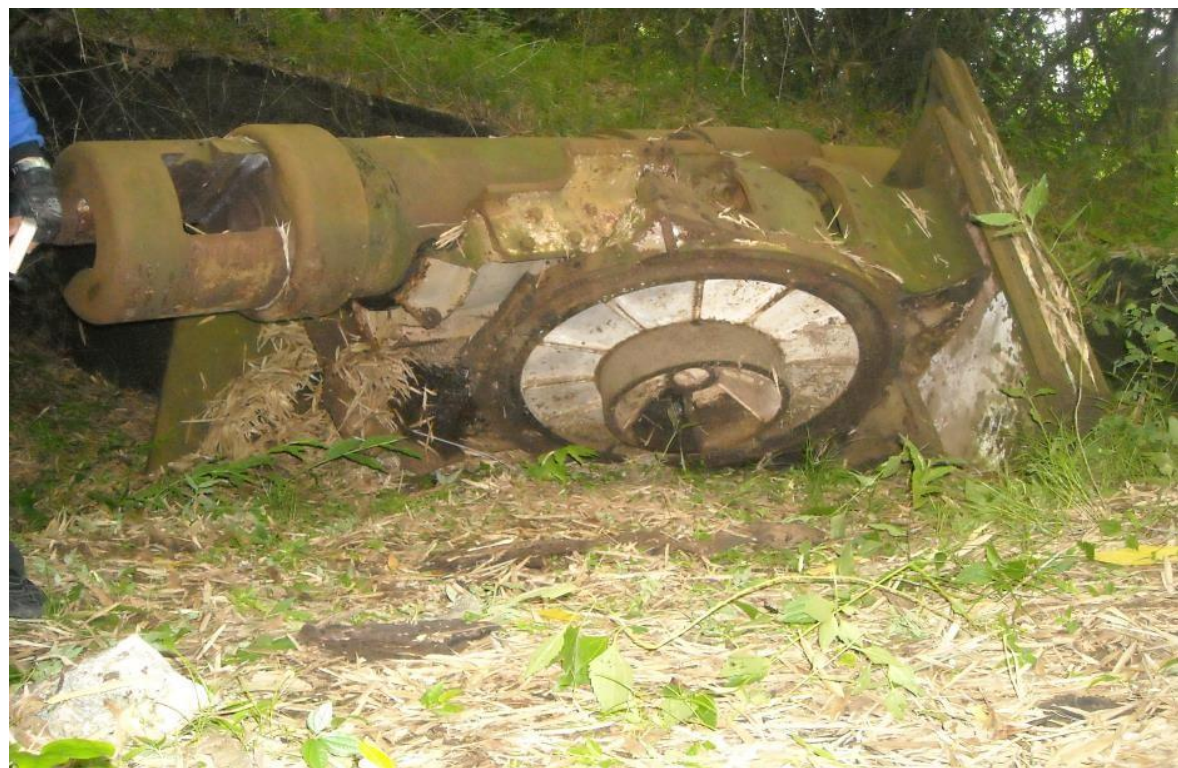

Gambar 10. Meriam yang terdapat di sembulungan (Sumber: dokumentasi pribadi 2020).

\section{Kesimpulan}

Berbagai peninggalan bersejarah di Indonesia merupakan bukti kemajuan peradaban bangsa. Oleh karena itu, kita sebagai bangsa wajib menghargai peninggalan bersejarah. Ada beberapa cara yang dapat dilakukan untuk menghargai peninggalan bersejarah

1. Memanfaatkannya Sebagai Objek Penelitian, Peninggalan bersejarah dapat dimanfaatkan sebagai objek penelitian. Peninggalan bersejarah merupakan bukti kehidupan dan peradaban di masa lalu. Pada peninggalan bersejarah terdapat riwayat sejarah yang bernilai tinggi jika kita teliti dengan seksama. Dan hasil penelitian tersebut akan terungkap kehidupan masyarakat di masa lalu untuk kita ambil alih hikmahnya

2. Memanfaatkannya Sebagai Objek Wisata, Peninggalan bersejarah dapat menarik wisatawan. Peninggalan bersejarah dapat mendatangkan kekaguman akan kebesaran masa lalu. Oleh karena itu peninggalan bersejarah dapat dijadikan objek wisata. Hal ini juga membawa keuntungan bagi pemerintah daerah dan masyarakat setempat.

3. Merawat Peninggalan Bersejarah, Perawatan peninggalan bersejarah dapat dilakukan oleh pemerintah, kelompok peduli lingkungan, dan masyarakat. Pemerintah dapat mengupayakan pemeliharaan dengan penyediaan anggaran. Anggaran tersebut digunakan oleh pemerintah daerah tempat peninggalan tersebut berada. Perawatan ini juga sebagai upaya melestarikan dan menghargai peninggalan bersejarah tersebut. Dengan demikian peninggalan bersejarah dapat dimanfaatkan oleh generasi penerus.

4. Memelihara dan menjaga peninggalan bersejarah merupakan kewajiban bagi seluruh masyarakat. 
GANDRUNG: Jurnal Pengabdian Kepada Masyarakat ISSN: 2721-6136 (Online)

Peninggalan bersejarah dilindungi oleh Undang Undang. Siapapun yang merusaknya akan dikenai sanksi hukum. Hal ini sebagai upaya pencegahan agar peninggalan bersejarah tidak rusak atauhancur. Pihak perorangan pun dapat berupaya secara pribadi dan bersifat sukarela merawat peninggalan bersejarah. Misalnya tidak mencoret coret benda peninggalan bersejarah. Tidak merusak atau mengambil bahkan menjual benda peninggalan bersejarah. Segala upaya perawatan itu merupakan wujud menghargai peninggalan bersejarah. Peninggalan bersejarah mempunyai nilai adiluhung dan berguna bagi bangsa Indonesia. Apabila peninggalan bersejarah lestari, maka generasi penerus dapat mengetahui peristiwa masa lalu bangsanya.

5. Merenovasi Peninggalan Bersejarah, Pihak pemerintah ikut merenovasi peninggalan bersejarah, baik secara mandiri maupun dengan bantuan lembaga dunia seperti UNESCO. Usaha ini dilakukan bila peninggalan bersejarah mengalami kerusakan. Baik kerusakan besar maupun kecil. Program renovasi ini dapat dilaksanakan secara berkala. Proses penanganannya pun harus hati hati agar nilai sejarah dari peninggalan tersebut tidak hilan.

Tahap renovasi biasanya melibatkan tenaga ahli khusus, biasanya orang yang ahli di bidang sejarah dan arkeologi. Usaha ini merupakan wujud menghargai karya nenek moyang di masa lalu. Tujuannya agar peninggalan bersejarah tetap kukuh dan kuat sebagai aset bangsa. Semenanjung Sembulungan banyak menyimpan potensi sejarah dan budaya mulai zaman Prasejarah, Kerajaan Majapahit-Blambangan, Penjajahan Kolonial Belanda-Jepang. Berikut hasil inventarisasi dan deskripsi potensi yang ada di Semenanjung Sembulungan mulai dari keberadaan makam, Goa, Bunker dan meriam. Sehingga dengan diadaknnya penelitian ini diharapkan adanya kesadaran pentingnya merawat dan peninggalan sejarah yang ada disekitar kita.

\section{Daftar Referensi}

Amboro, K. (2020). Sejarah Publik dan Pendidikan Sejarah Bagi Masyarakat. Jurnal Historis: Jurnal Kajian, Penelitian \& Pengembangan Pendidikan Sejarah, 5(1).

Aramdi, Z. N. (2020). Sejarah, Kedudukan, Dan Fungsi Bahasa Indonesia. Jurnal Bahasa.

Asvi Warman Adam. (2007). Seabad Kontroversi Sejarah. Ombak. https://www.goodreads.com/book/show/2868073-seabad-kontroversi-sejarah

Azizah, F. N., \& Turyati. (2011). Gandrung dalam Upacara Ritual Petik Laut di Pantai Muncar Kabupaten Banyuwangi. Jurnal Ilmiah Seni Makalangan.

Hennida, C., Felayati, R. A., Wijayanti, S. H., \& Perdana, A. R. (2017). Budaya dan Pembangunan Ekonomi di Jepang, Korea Selatan dan China. Jurnal Global \& Strategis, 10(2). 
GANDRUNG: Jurnal Pengabdian Kepada Masyarakat ISSN: 2721-6136 (Online)

https://doi.org/10.20473/jgs.10.2.2016.248-263

Khoirotun, A., Fianto, A. Y. A., \& Riqqoh, A. K. (2014). Perancangan buku pop-up museum Sangiran sebagai media pembelajaran tentang peninggalan sejarah. Jurnal Desain Komunikasi Visual, 2(1). Kurniawan, H. (2020). Infografik Sejarah Dalam Media Sosial : Tren Pendidikan Sejarah Publik. Sejarah Dan Budaya, 14(2).

M. Dien Madjid, J. W. (2014). IImu Sejarah: Sebuah Pengnatar. Kencana.

Mursidi, A., \& Soetopo, D. (2019). Peninggalan Sejarah Sebagai Sumber Belajar Sejarah Dalam Penanaman Nilai-Nila Kebangsaan Di Kecamatan Muncar Kabupaten Banyuwangi. Khazanah Pendidikan, XIII(1).

Noviandari, H. dan A. M. (2019). Identifikasi Dini Guna Mengoptimalkan Kemampuan Bahasa pada Anak Tuna Rungu Usia Pra Sekolah. Jurnal Psikologi, 6(1).

Salim Yulius, H. W. L. . Y. (2014). Identifikasi Selat Di Kabupaten Karimun Provinsi Kepulauan Riau Berdasarkan Kaidah Toponimi (Strait Identification in Karimun Regency Riau Islands Province Based on Toponymy Method). Jurnal Saintek Perikanan, Vol 9, No 2 (2014): Jurnal Saintek Perikanan, 1-10. http://ejournal.undip.ac.id/index.php/saintek/ article/view/8116

Saripudin, D., Yulifar, L., \& Anggraini, D. N. (2021). Pelatihan Pembuatan dan Pemanfaatan Replika Sejarah dan Peta E-Pen Bagi Guru-Guru SMA/MA. Abdi: Jurnal Pengabdian Dan Pemberdayaan Masyarakat, 3(1). https://doi.org/10.24036/abdi.v3i1.76

Sudirman, A. (2014). Sejarah Lengkap Indonesia: Dari Era Klasik Hinga Terkini. Diva Press.

Uliontang, U., Setyati, E., \& Chandra, F. H. (2020). Pemanfaatan Augmented Reality Pada Media Pembelajaran Sejarah Tentang Benda-Benda Bersejarah Peninggalan Kerajaan Majapahit Di Trowulan Mojokerto. Teknika: Engineering and Sains Journal, 4(1). https://doi.org/10.51804/tesj.v4i1.785.19-26 